\title{
Diversity of Plants Species Abundantly Consumed In Traditional Practice of Siamese Community of Kelantan, Malaysia
}

\author{
Aweng Eh Rak ${ }^{1}$, Karunakaran Tharmadurai ${ }^{1}$, Zakia Khanam², Sharifah Aisyah \\ Syed Omar ${ }^{1}$ and Suganthi Appalasamy ${ }^{1}$ \\ \{aweng@umk.edu.my\} \\ ${ }^{1}$ Faculty of Earth Science, Universiti Malaysia Kelantan, Jeli Campus, 17600 Jeli, Kelantan, \\ Malaysia. \\ ${ }^{2}$ Faculty of Agro Based Industry, Universiti Malaysia Kelantan, Jeli Campus, 17600 Jeli, \\ Kelantan, Malaysia.
}

\begin{abstract}
Siamese community in Kelantan are more health conscious by taking plants with medicinal value as daily dietary intake but type of plants and its traditional use yet to be explore and recorded. The objective is to identify and document plants and plant parts those are being consumed and the traditional uses. Plants that are being consumed by Siamese community in three main localities were recorded by a verbal interview with old folks of the village. Plants were collected with the guide of the old folks for identification. From the identified names, further information was collected through literature reviewed on their recorded medicinal values. A total of 20 plants were collected, identified and reported. The plants belong to 16 families. The list of plants recorded serves as a datasheet for the study of plants with medicinal value consumed by Siamese community of Kelantan.
\end{abstract}

Keywords: traditional use, medicinal value, health conscious, old folk, Siamese community

\section{Introduction}

Food has been the biggest need in daily life for all life forms. Among humans, healthy and nutritional food has been basic requirement. Healthy and nutritional food provides a balanced dietary intake of vitamins, protein, fat, energy, calories, and antioxidant compounds [1], [2]. Not only that, healthy and nutritional food contain antibacterial, anticarcinogenic, anti-fungal and other medicinal compounds concerning to health maintenance [3]-[5]. These compounds even though can be found in most organic food sources, plant source has been regarded the best in terms of the quality and quantity of the compounds acquired. This has been proven in traditional practice as most of the traditional healer or medicine practitioner use mostly plant parts as ailments for curing illnesses [6]-[9].

Traditional medicine has been regarded as the basis of all modern medicine as it serves as a platform where researchers look to in discovering medicinal source or ideas to explore in new medicine development [10] As such, many cultures throughout the globe have their respective traditional medicine practice which sometimes coincides and also contradicts with other cultures. One of such culture is the Siamese community of Kelantan, Malaysia. The Siamese community has long have adapted to the culture and lifestyle of the local community. Somehow, their traditions have remained intact and unchanged with the tradition of Thailand community. They daily lifestyle such as food and other intrinsic parts of life still shows their 
origin from Thailand. Apart from that, when we investigate into their routine food consumption, it shows that they are more health conscious by taking plants with medicinal value as daily dietary intake to maintain good health. Thus, this paper will discuss on identified plant and their parts that was consumed by Siamese community and their traditional uses.

\section{Methodology}

The sample collection and data collection via interview were conducted in three villages namely Kubang Panjang, Kampung Kuang and Kampung Mentua, Kelantan (Figure 1). Information's were collected through verbal interview with the old folks from each of the village comprising of 10 to 15 people aged 55-70. Some of the individuals are traditional healers and regular consumer of the plants listed in this paper. The plant specimens were collected with the help of the villagers. The specimens were identified by Dr. Shamsul Khamis (Senior Lecturer/Botanist) from Universiti Putra Malaysia and Mr. Ahmad Fitri, from Institute of Environmental Science and Natural Resource, Faculty of Science and Technology, Universiti Kebangsaan Malaysia.

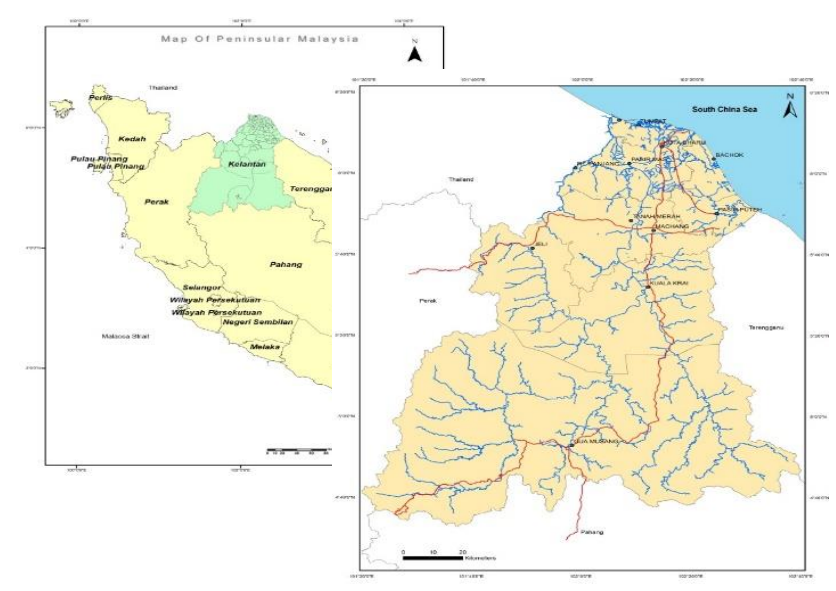

Fig. 1. Study Sites

\section{Results And Discussion}

In overall of 21 species plants belonging to 16 families were collected, identified and reviewed. The plants were listed and discussed accordingto collected information frominterviewedandliteraturereview. The lists of plant werearranged by family, botanical name, native name (EN: English name, SN: Siamese name/ MN: Malay name), physical description and previously studied uses of the plant's parts.

[F: Acanthaceae] Achanthus ebracteatus (EN: Sea Holly, MN: Jejuru hitam, SN: Khem pla mor) is a shrub, commonly found in estuarine zones and can grow to a height of $1.5 \mathrm{~m}$. Their leaves are dark green in colour, with sharp spines. They have white flower which turns brown when matures[11]. They also produce fruit. The leaves are used to treat boils, hair loss, purify blood and snake bites [12], [13]. The root and stem are used to treat cough, chronic fever, paralysis, asthma, hepatitis and skin allergies [12], [14]. 
[F: Bignoniaceae] Oroxylum indicum (EN: Indian trumpet, SN: Phaekaa) is a large tree plant. It produces seeds in a bean shaped case. The plants are used for treating fever, bronchitis, diarrhoea, inflammation, ulcer, jaundice and cancer [15], [16].

[F: Costaceae] Cheilocostus speciosus (EN: Spiral ginger, SN: Eang). The plant has a rigid stem, red or green coloured and grows in a spiral form. The leaves are oblong shaped and grow on one side of the stem along the spiral looking like a spiral staircase. It produces white flowers on a lush red bulb that resembles a pine cone. The rhizomes are known to be used for kidney stone and jaundice [17].

[F: Cucurbitacea] Coccinia grandis (EN: Ivy gourd, MN: Timun tikus, SN: Tam loeng) is climber plant that produces white flowers and fruits which are green when young that turns red when ripe The plant is highly valued for its medicinal value in treating diabetic patient [18].

[F: Euphorbiaceae] Mallotus paniculatus (EN: Turn-in-the-wind, MN: Balik angin bukit, $\mathrm{SN}$ : Lang khau) is a tree that wildly grows everywhere. It can be easily distinguished by the broad leaf structure with three pointy edges and the lower leaf is whitish brown coloured, sometimes appears to look like gold coloured. It had black coloured fruits and flowers are small and produced on soft stem at the edge of each branch. The records of traditional uses in other communities are example; fruits used for contusions and traumatic injuries and oedema. Root are used for gynecological infection and the whole plant are reported to be effective for fever, headache, wound healing [19].

[F: Euphorbiaceae] Sauropus androgynous (EN: Star gooseberry, MN: Sayur manis, SN: Pak waan) tree are very common plant that grows large and has fruits white or greenish yellow with flowers of red colour. It serves as a natural remedy for fever, earache, urinary problem and stimulates lactation [20], [21].

[F: Fabaceae] Clitoria ternatea (EN: Butterfly pea, MN: Bunga telang, SN: Anchan) is a climber plant with purple coloured flower. The whole plant has multiple uses. The plants are known to be useful in treating infections and burning sensation in the urinary tract, lack of urination, edema, antidote, tumour, snake bite, indigestion, cough, headache, eye diseases and arthritis [22], [23].

[F: Flagellariaceae] Flagellarian indica (EN: False rattan, MN: Rotan dini, SN: Wai ling) found growing in wild bushes. Their stems are rigid and usually creep along bushes which grow long in length. They produce small sized fruits pinkish in colour. Their leaves are traditionally used as cardiotonic, antenatal care and rhizome are used as a treatment for fever, malaria and jaundice[24].

[F: Lamiaceae] Vitex negundo (EN: Five-leaved chaste tree, SN: Khai now meing) large aromatic shrub that hard stem. The plants are easily distinguished by the 5 foliage leaf structure. The flowers produced are small in size and resembles the orchid flower structure with white and light purple colour. In previously reported studies, he plant have shown medicinal properties such as antiseptic, rejuvenating, anti-gonorrhoeic, anti-inflammatory, diuretic, dysentery, wound healing, ulcers, useful for bronchitis and asthma, menstrual period, amenorrhea (abnormal suppression of menstruation) and dysmenorrhea (painful menstruation) [25], [26].

[F: Lamiaceae] Vitex trifolia (EN: Simple leaf chaste tree, MN: Laguni pantai, SN: Kunthi) is a shrub that mostly found along beachside. The usually creep along the sandy beach and grow into small shrub where each shrub are connected. They produce purplish flowers and small round fruits which are green when young and turn brown when matured. The plant have shown to be utilised as a natural remedy for ring worm problem, tuberculosis, joint pains, skin 
allergies or rashes, leprosy, inflammation, analgesic, anticonvulsant, insecticidal, antiemetic, fungicidal and rheumatic pain [27], [28].

[F: Lygodaceae] Lygodium microphyllum (EN: Snake fern, SN: Rebunyung) is a fern like plant. Mostly, found nearby river area where the soil is moist with bushes which allows this plant to crepe for support. It has few traditional medicine uses. It can be used to treat dysentery, skin disease and swelling [29], [30].

[F: Melastomataceae] Melastoma malabathricum (EN: Singapore rhododendron, SN: Khering) are common shrub plant with brown-red soft stem and leaves with rough surface due to minute hair like structure. The flowers are purple in colour and become fruit in a bulb shape with reddish surface colour. It is used traditionally in treating diarrhoea, dysentery, wound healing, post-partum treatment puerperal infection, leucorrhoea and haemorrhoids [31].

[F: Pandanaceae] Pandanus amaryllifolius (EN: Pandan leaves, MN: Daun pandan, SN: Bai panan) is a famous plant for its fragrant leaves. Common uses are in food preparation but their roots are utilised as treatment for diabetic patients, cold, fever, bleeding after parturition and as insect repellent [32], [33].

[F: Rutaceae] Citrus aurantifolia swingle (EN: Lime, MN: Limau nipis SN: Manau) is a commercial species largely used in various communities in extensive application. The leaves are thick, while the fruits are small and smooth surfaced. The plant produces white flowers with light yellow coloured centre. Leaves are good in relieving fever, headache and cold [23]. Stem bark are used by communities in the western Africa as treatment for hypertension [34]. Some other common uses of these plants are treating gastrointestinal disorders, fever, malaria, scabies and diabetes [35].

[F: Rutaceae] Citrus hystrix (EN: Kaffir lime, MN: Limau purut, SN: Makrut) is a wellknown plant especially to the Asian culture due to its extensive uses in Asian culinary. The leaves are twin like shaped while the fruits surface looks uneven. The flowers produced are white coloured. It is regularly used by many communities to treat skin diseases, headache, flu, fever, sore throats, bad breath and indigestion [36], [37].

[F: Rutaceae] Micromelum minutum (EN: Lime berry, SN: Semui) is a shrub plant. It grows wildly in bushes. It has a similar smell and leaf structure of curry leaves. The difference is the leaves are bigger and lighter in colour compared to curry leaves. The plant have shown to be useful in cases of ulcer, tuberculosis, as anti-hyperglycaemic, anti-hyperlipidaemia and anti-apoptotic [38]-[40]

[F: Sapindaceae] Allophylus cobbe (EN: Titberry, SN: Sepsai) is a small shrub that has tri-foliage leave arrangements. Leaves are light green in colour and small spore like flower structure will be visible at the peak of the branch like a stamen. Thetree has multiple uses of all its parts. Leaves are used to treat fever, inflammation, ulcer, induce lactation and rheumatic pains, meanwhile root or stem are used to relieve joint and muscle pain [24], [41], [42].

[F: Selaginellaceae] Selaginella alutacia (EN: Starry spikemoss, SN: Wew knok jung) are fern like plant with the colour appearing bluish-green. It can been utilised as treatment for wound, menstruation, uterine disorder, internal injuries, heat stroke and jaundice [43], [44].

[F: Smilacaceae] Smilax calophylla (EN: Catbriers, MN: Rancang tembaga, SN: Kethart) are vining type plant with thorn along the stem. The leaves are thick and have clear vein structure. It is believed to be male sexual tonic and used as treatment for cases like gonorrhoea and edema [45].

[F: Verbenaceae] Clerodendrum indicum (EN: Tuberflower, SN: Thao jaimom) is a small plant with thin, narrow leaves. Two leaves in every layer throughout the stem arranged alternatingly. The flowers are white in colour with long pedicle. The centre of flower has slight pink colouration with protruding stamen. The plants had been studied to possess 
antimicrobial, antidiarrheal, anti-nociceptive activities, useful for asthma, cataract, malaria, skin disease, lung related problem, syphilis, typhoid, cancer, jaundice and hypertension[46], [47].

[F: Verbenaceae] Premna serratifolia (EN: Bastard Guelder, MN: Buas buas, SN: Sap reng) is a small shrub that has light green leaves with a medicinal smell. The leaves are broad and the plant produce small bud like white coloured flowers. The whole plant was studied to contain valuable medicinal properties useful as treatment for cardiovascular diseases, skin infection, inflammatory problem, arthritis, gonorrhoea, rheumatism, anorexia, jaundice, diabetes, bronchitis, dyspepsia, liver problem, piles, antitumor, etc. [48], [49].

Table 1 showed the summaryoftraditionalusesfortheidentifiedplants. It can be conclude that, a plant can be used to treat more than one disease except Coccinia grandis which only traditionally used as medicine for diabetic patient. The anti-hyperglycemic, $\beta$-cell regenerative, antihyperlipidemic and antioxidant properties containedinthisplantwereclaimed hasa therapeutic potentialfor diabetes [50].

Table 1. Summary of traditionalmedicinalusedusingselected plant.

\begin{tabular}{|c|c|c|}
\hline No. & Scientific name & Traditional medicinal uses \\
\hline 1 & Achanthus ebracteatus & $\begin{array}{l}\text { Cough, chronic fever, paralysis, asthma, hepatitis and skin } \\
\text { allergies }\end{array}$ \\
\hline 2 & Oroxylum indicum & $\begin{array}{l}\text { Fever, bronchitis, diarrhoea, inflammation, ulcer, jaundice } \\
\text { and cancer }\end{array}$ \\
\hline 3 & Cheilocostus speciosus & Kidney stone and jaundice \\
\hline 4 & Coccinia grandis & Diabetic patient \\
\hline 5 & Mallotus paniculatus & $\begin{array}{l}\text { Contusions, traumatic injuries, oedema, gynecological } \\
\text { infection, fever, headache and wound healing }\end{array}$ \\
\hline 6 & Sauropus androgynous & Fever, earache, urinary problem and stimulates lactation \\
\hline 7 & Clitoria ternatea & $\begin{array}{l}\text { Infections and burning sensation in the urinary tract, lack of } \\
\text { urination, edema, antidote, tumour, snake bite, indigestion, } \\
\text { cough, headache, eye diseases and arthritis }\end{array}$ \\
\hline 8 & Flagellarian indica & Cardiotonic, antenatal care, fever, malaria and jaundice. \\
\hline 9 & Vitex negundo & $\begin{array}{l}\text { Antiseptic, rejuvenating, anti-gonorrhoeic, anti- } \\
\text { inflammatory, diuretic, dysentery, wound healing, ulcers, } \\
\text { useful for bronchitis, asthma, menstrual period, amenorrhea } \\
\text { (abnormal suppression of menstruation) and dysmenorrhea } \\
\text { (painful menstruation) }\end{array}$ \\
\hline 10 & Vitex trifolia & $\begin{array}{l}\text { Ring worm problem, tuberculosis, joint pains, skin allergies } \\
\text { or rashes, leprosy, inflammation, analgesic, anticonvulsant, } \\
\text { insecticidal, antiemetic, fungicidal and rheumatic pain. }\end{array}$ \\
\hline 11 & Lygodium microphyllum & Dysentery, skin disease and swelling \\
\hline 12 & $\begin{array}{l}\text { Melastoma } \\
\text { malabathricum }\end{array}$ & $\begin{array}{l}\text { Diarrhoea, dysentery, wound healing, post-partum treatment } \\
\text { puerperal infection, leucorrhoea and haemorrhoids }\end{array}$ \\
\hline 13 & Pandanus amaryllifolius & $\begin{array}{l}\text { Diabetic patients, cold, fever, bleeding after parturition and } \\
\text { as insect repellent }\end{array}$ \\
\hline 14 & $\begin{array}{l}\text { Citrus aurantifolia } \\
\text { swingle }\end{array}$ & $\begin{array}{l}\text { Fever, headache, cold, hypertension, gastrointestinal } \\
\text { disorders, fever, malaria, scabies and diabetes. }\end{array}$ \\
\hline 15 & Citrus hystrix & $\begin{array}{l}\text { Skin diseases, headache, flu, fever, sore throats, bad breath } \\
\text { and indigestion }\end{array}$ \\
\hline 16 & Micromelum minutum & $\begin{array}{l}\text { Ulcer, tuberculosis, as anti-hyperglycaemic, anti- } \\
\text { hyperlipidaemia and anti-apoptotic }\end{array}$ \\
\hline
\end{tabular}




\begin{tabular}{ccl}
\hline No. & Scientific name & \multicolumn{1}{c}{ Traditional medicinal uses } \\
\hline 17 & Allophylus cobbe & $\begin{array}{l}\text { Fever, inflammation, ulcer, induce lactation, rheumatic } \\
\text { pains, relieve joint and muscle pain }\end{array}$ \\
\hline 18 & Selaginella willdenowii & $\begin{array}{l}\text { Wound, menstruation, uterine disorder, internal injuries, heat } \\
\text { stroke and jaundice }\end{array}$ \\
\hline 19 & Smilax calophylla & Male sexual tonic, gonorrhoea and edema \\
\hline 20 & Clerodendrum indicum & $\begin{array}{l}\text { Antimicrobial, antidiarrheal, antinociceptive activities, useful } \\
\text { for asthma, cataract, malaria, skin disease, lung related } \\
\text { problem, syphilis, typhoid, cancer, jaundice and hypertension }\end{array}$ \\
\hline 21 & Premna serratifolia & $\begin{array}{l}\text { Cardiovascular diseases, skin infection, inflammatory } \\
\text { problem, arthritis, gonorrhoea, rheumatism, anorexia, } \\
\text { jaundice, diabetes, bronchitis, dyspepsia, liver problem, } \\
\text { piles, antitumor, etc. }\end{array}$ \\
\hline
\end{tabular}

\section{Conclusions}

The review of the selected plants illustrates the level of health consciousness of the village folk in their dietary intake. The plants identified to be consumed by the villagers are found to be highly nutritional, healthy and at the same time to provide wide range of medicinal benefits that could protect the body from various diseases. This is a clear indication of healthy diet and living by the simplest mean of food consumption which largely based on fresh and natural food sources. This review provides additional information for future in depth study into the consumption of herbal plants among the Siamese community to unveil more substantial evidence on the nutritional value of the plants being consumed. Due to the evidence from previous studies supporting that the plants listed having potential as a treatment for severe diseases such as cardiovascular disease, diabetes, cancer, gonorrhoea, tuberculosis as well as other illnesses, there are space and gaps that can be further studied to improve as well as create better nature based medication in combating health related problems faced by the human population.

\section{Acknowledgements}

This research was supported by Fundamental Research Grant Scheme [R/FRGS/A08.00/00244A/003/2014/000181] by Department of Higher Education, Ministry of Education Malaysia.

\section{References}

[1] R. L. Prior and X. Wu, "Diet Antioxidant Capacity: Relationships to Oxidative Stress and Health,” Am. J. Biomed. Sci., pp. 126-139, Apr. 2013.

[2] M. A. Stipanuk, M. H. \& Caudill, Biochemical, physiological, and molecular aspects of human nutrition: Elsevier health sciences, 2013.

[3] P. A. v. d. Geybels, M. S., Verhage, B. A. J., Arts, I. C. W., Frederik J. van Schooten, Goldbohm, R. A. \& Brandt, "Dietary flavonoid intake, black tea consumption, and risk of overall and advanced stage prostate cancer.," Am. J. Epidemiol., vol. 177, no. 12, pp. 13881398, 2013.

[4] M. M. Muruganantham, N., Solomon, S. \& Senthamilselvi, "Antimicrobial activity of Cucurbita maxima flowers (Pumpkin). and Phytochemistry,” J. Pharmacogn., vol. 5, no. 1, pp. 15-18, 2016. 
[5] S. Vazhacharickal, P. J., Sajeshkumar, N. K., Mathew, J. J., Kuriakose, A. C., Abraham, B., Mathew, R. J., Albin, A. N., Thomson, D., Thomas, R. S., Varghese, N. \& Jose, "Chemistry and medicinal properties of jackfruit (Artocarpus heterophyllus): A review on current status of knowledge.," Int. J. Innov. Res. Rev., vol. 3, no. 2, pp. 83-95, 2015.

[6] P. Bunalema, L., Obakiro, S., Tabuti, J. R. S. \& Waako, "Knowledge on plants used traditionally in the treatment of tuberculosis in Uganda," J Ethnopharmacol, vol. 151, pp. 9991004, 2014.

[7] R. Rahmatullah, M., Khatun, Z., Barua, D., Alam, M.-U., Jahan, S. \& Jahan, "Medicinal plants used by traditional practitioners of the Kole and Rai Tribes of Bangladesh.," J. Altern. Complement. Med., vol. 19, no. 6, pp. 483-491, 2013.

[8] J. G. Ganga, G. \& Houdijk, "Tolossa, K., Debela, E., Athanasiadou, S., Tolera, A., Ethnomedicinal study of plants used for treatment of human and livestock ailments by traditional healers in South Omo, Southern Ethiopia.," J. Ethnobiol. Ethnomed., vol. 9, no. 32, 2013.

[9] R. Vijayakumar, S., Yabesh, J. E. M., Prabhu, S., Ayyanar, M. \& Damodaran, "Ethnozoological study of animals used by traditional healers in Silent Valley of Kerala, India.," $J$ Ethnopharmacol, vol. 162, 2015.

[10] K. M. Pan, S.Y., Zhou, S.F., Gao, S.H., Yu, Z.L., Zhang, S.F., Tang, M.K., Sun, J.N., Ma, D.L., Han, Y.F., Fong, W.F. \& Ko, "New perspectives on how to discover drugs from herbal medicines: CAM's outstanding contribution to modern therapeutics.," Evidence-Based Complement. Altern. Med., 2013.

[11] D. M. Robertson, A. I. \& Alongi, Tropical mangrove ecosystems. Washington, DC: American Geophysical Union, 1992.

[12] J. Somchaichana, T. Bunaprasert, and S. Patumraj, “Acanthus ebracteatus Vahl. Ethanol Extract Enhancement of the Efficacy of the Collagen Scaffold in Wound Closure: A Study in a FullThickness-Wound Mouse Model," J. Biomed. Biotechnol., vol. 2012, pp. 1-8, 2012.

[13] B. C. Subudhi, H. N., Choudhury, B. P. \& Acharya, "Some potential medicinal plants of Mahanadi delta in the state of Orissa," J. Econ. Taxon. Bot., vol. 16, no. 2, pp. 479-487, 1992.

[14] L. M. Perry, Medicinal Plants of East and Southeast Asia Attributed Properties and Use (Vol. 2). London, UK.: The Massachusetts Institute of Technology Press, 1980.

[15] V. Bisht, A., Zaman, K., Singh, M., Gupta, R. \& Singh, "Pharmacognostical studies on Oroxylum indicum (Linn.) vent. stem bark.," Indian J. Nat. Prod. Resour., vol. 2, no. 4, pp. 472-478, 2011.

[16] A. K. Harminder, S. V. \& Chaudhar, "A Review on the taxonomy, ethnobotany, chemistry and pharmacology of Oroxylum indicum vent.," Indian J. Pharm. Sci., vol. 73, no. 5, p. 483-490, 2011.

[17] R. Priya, V. K. J. \& Gopalan, "Ethnomedicinal studies in selected medicinal plants of dhoni forest, Western Ghats, Kerala.," Asian J Pharm Clin Res., vol. 7, no. 3, pp. 3-6, 2014.

[18] K. P. Munasinghe, M. A., Abeysena, C., Yaddehige, I. S., Vidanapathirana, T. \& Piyumal, "Blood sugar lowering effect of Coccinia grandis (L.) J. Voigt: path for a new drug for diabetes mellitus.," Exp. Diabetes Res., p. 4, 2011.

[19] C. Rivière et al., "Mallotus species from Vietnamese mountainous areas: phytochemistry and pharmacological activities," Phytochem. Rev., vol. 9, no. 2, pp. 217-253, Jun. 2010.

[20] N. M. Bunawan, H., Bunawan, S. N., Baharum, S. N. \& Noor, "Review article Sauropus androgynus (L.) Merr. induced bronchiolitis obliterans: from botanical studies to toxicology.," Evidence-Based Complement. Altern. Med., pp. 1-7, 2015.

[21] D. F. Wei, L. S., Wee, W., Siong, J. Y. F. \& Syamsumir, "Characterization of antimicrobial, antioxidant,anticancer properties and chemical composition of Sauropus androgynus stem extract.," Acta Medica Litu., vol. 18, no. 1, pp. 12-16, 2011.

[22] M. Hossan, M. S., Hanif, A., Agarwala, B., Sarwar, M. S., Karim, M., Taufiq-Ur-Rahman, M., Jahan, R. \& Rahmatullah, "Traditional use of medicinal plants in Bangladesh to treat urinary tract infections and sexually transmitted diseases.," Ethnobot. Res. Appl., vol. 8, 2010.

[23] S. Muthu, C., Ayyanar, M., Raja, N. \& Ignacimuthu, "Medicinal plants used by traditional healers in Kancheepuram district of Tamil Nadu, India.," J. Ethnobiol. Ethnomed., vol. 2, no. 
43, 2006

[24] K. Y. and N. S. Oratai Neamsuvan, Patcharin Singdam, "A survey of medicinal plants in mangrove and beach forests from sating Phra Peninsula, Songkhla Province, Thailand," J. Med. Plants Res., vol. 6, no. 12, Mar. 2012.

[25] K. K. Rana, S. \& Rana, "Review on medicinal usefulness of Vitex negundo Linn.," Open Access Libr. J., vol. 1, pp. 1-13, 2014.

[26] V. R. Tandon, "Medicinal uses and biological activities of Vitex negundo.," Nat. Prod. Radiance, vol. 4, no. 3, pp. 162-165, 2005.

[27] L. A. Kulkari, "Pharmacological review of Vitex negundo Linn. (Verbaeaceae).," Pharmacologyonline, vol. 3, pp. 858-863, 2011.

[28] C. H. Venkateshwarlu, G., Ragyanaik, E., Swapna, K., Santhosh, A. \& Santhosh, "Vitex trifolia-an important medicinal plant: A review of its folklore medicine and traditional uses.," Asian J. Pharm. Res., vol. 4, no. 2, pp. 70-71, 2014.

[29] T. Panda, S. K., Rout, S. D., Mishra, N. \& Panda, "Phytotherapy and traditional knowledge of tribal communities of Mayurbhanj district, Orissa, India. Phytotherapy," J. Pharmacogn., vol. 3, no. 7, pp. 101-113, 2011.

[30] N. Rout, S. D., Panda, T. \& Mishra, "Ethnomedicinal studies on some pteridophytes of Similipal Biosphere Reserve, Orissa, India.," Int. J. Med. Med. Sci., vol. 1, no. 5, 2009.

[31] R. M. Susanti, D., Sirat, H. M., Ahmad, F. \& Ali, "Bioactive constituents from the leaves of Melastoma malabathricum L.," J. Ilm. Farmas, vol. 5, no. 1, 2008.

[32] S. H. Li, J. \& Ho, "Pandan leaves (Pandanus amaryllifolius Roxb.) as a natural cockroach repellent.," in Proceedings of the 9th National Undergraduate Research Opportunities Programme., 2003.

[33] T. J. Sharma, P. C., Yelne, M. B. \& Dennis, Database on medicinal plants used in ayurveda. New Dehli, 2001.

[34] A. E. A. Abo, K. A., Fred-Jaiyesimi, A. A. \& Jaiyesimi, "Ethnobotanical studies of medicinal plants used in the management of diabetes mellitus in South Western Nigeria," $J$ Ethnopharmacol, vol. 115, pp. 67-71, 2008.

[35] D. D. Das, F. A., Barua, I. \& Das, "Ethno-medicinal practices: A case study among the Sonowal Kacharis of Dibrugarh, Assam.," Ethno-Med., vol. 2, no. 1, pp. 33-37, 2008.

[36] A. Abirami, G. Nagarani, and P. Siddhuraju, "In vitro antioxidant, anti-diabetic, cholinesterase and tyrosinase inhibitory potential of fresh juice from Citrus hystrix and C. maxima fruits," Food Sci. Hum. Wellness, vol. 3, no. 1, pp. 16-25, Mar. 2014.

[37] W. S. S. W. Aziman, N., Abdullah, N., Noor, Z. M., Zulkifli, K. S. \& Kamarudin, "Phytochemical constituents and In Vitro bioactivity of ethanolic aromatic herb extracts.," Sains Malaysiana, vol. 41, no. 11, pp. 1437-1444, 2012.

[38] E. Elkington, B. G., Sydara, K., Newsome, A., Hwang, C. H., Lankin, D. C., Simmler, C., Napolitano, J. G., Ree, R., Graham, J. G., Gyllenhaal, C., Bouamanivong, S., Souliya, O., Pauli, G. F., Franzblau, S. G. \& Djaja Djendoel Soejarto a, "New finding of an anti-TB compound in the genus marsypopetalum (Annonaceae) from a traditional herbal remedy of Laos.," $J$ Ethnopharmacol, vol. 151, pp. 903-911, 2014.

[39] N. R. Koriem, K. M., Aminuddin, M. E., Kader, A. S. \& Sheikh, "Antihyperglycemic, antihyperlipidemic and antiapoptotic activities of Micromelum minutum seeds in diabetic rats.," J. Mol. Genet. Med., vol. S1, 2013.

[40] T. Srisawat, A. Suvarnasingh, and K. Maneenoon, "Traditional Medicinal Plants Notably Used to Treat Skin Disorders Nearby Khao Luang Mountain Hills Region, Nakhon Si Thammarat, Southern Thailand," J. Herbs. Spices Med. Plants, vol. 22, no. 1, pp. 35-56, Jan. 2016.

[41] S. A. Mandade, R. \& Sreenivas, "A review on gastric ulcer remedies used in ayurvedic system of medicine.," Int. J. Institutional Pharm. Life Sci., vol. 2, no. 1, pp. 95-104, 2012.

[42] H. M. Jain, P., Hossain, M. S., Fatema, K., Hossain, M. A. A., Mazumder, K. U., Hossain, H., Alam, M. A. \& Reza, "Anti-inflammatory, analgesic and antioxidant activities of Allophylus cobbe leaves. American,” J. Pharmacol. Toxicol., vol. 9, no. 4, pp. 223-231, 2014.

[43] R. Antony, R. \& Thomas, "A mini review on medicinal properties of the resurrecting plant 
Selaginella bryopteris (Sanjeevani)," Int. J. Pharm. Life Sci., vol. 2, no. 7, pp. 933-939, 2011.

[44] R. Ganeshaiah, K. N., Vasudeva, R. \& Uma, "In search of Sanjeevani.," Curr. Sci., vol. 97, no. 4, 2009.

[45] B. A. K. Nuraliza, A. S., Nwe, K. H. H., Morat, P. B., Hamid, A. \& Khalid, "The effect of Smilax calophylla on testicular 11ß-hydroxysteroid dehydrogenase activity and plasma testosterone levels in rats.," Biomed. Res., vol. 17, no. 1, pp. 55-59, 2006.

[46] S. N. Chandrashekar, R. \& Rao, "Acute anti-inflammatory activity of ethanolic extract of leaves of Clerodendrum viscosum by carrageenin induced paw oedema method in wistar albino rats.," Int. J. Res. Ayurveda Pharm, vol. 4, no. 2, pp. 224-227, 2013.

[47] A. Pal, Z. Al Mahmud, N. Akter, S. Islam, and S. C. Bachar, "Evaluation of Antinociceptive, Antidiarrheal and Antimicrobial Activities of Leaf Extracts of Clerodendrum indicum," Pharmacogn. J., vol. 4, no. 30, pp. 41-46, Jul. 2012.

[48] R. Muthukumaran, P., Salomi, S. \& Umamaheswari, "In vitro antioxidant activity of Premna serratifolia Linn.," Asian J. Res. Pharm. Sci., vol. 3, no. 1, pp. 15-18, 2013.

[49] N. M. S. Vadivu, R., Suresh, J. A., Girinath, K., Kannan, B. P., Vimala, R. \& Kumar, "Evaluation of hepatoprotective and in-vitro cytotoxic activity of leaves of Premna serratifolia Linn.," J. Sci Res, vol. 1, pp. 145-152, 2009.

[50] L. K. B. Attanayake, A. P., Jayatilaka, K.A.P.W. and Mudduwa, "Anti-diabetic potential of ivy gourd (Coccinia grandis, family: Cucurbitaceae) grown in Sri Lanka: A review.," $J$. Pharmacogn. Phytochem., vol. 5, no. 6, pp. 286-289, 2016. 